\title{
Molten salts in a bubble column reactor as catalysts for the oxidative coupling of methane
}

\section{Citation for published version (APA):}

Geerts, J. W. M. H., Kasteren, van, J. M. N., \& Wiele, van der, K. (1990). Molten salts in a bubble column reactor as catalysts for the oxidative coupling of methane. Journal of the Chemical Society, Chemical Communications,

(11), 802-803. https://doi.org/10.1039/c39900000802

DOI:

10.1039/c39900000802

Document status and date:

Published: 01/01/1990

\section{Document Version:}

Publisher's PDF, also known as Version of Record (includes final page, issue and volume numbers)

\section{Please check the document version of this publication:}

- A submitted manuscript is the version of the article upon submission and before peer-review. There can be important differences between the submitted version and the official published version of record. People interested in the research are advised to contact the author for the final version of the publication, or visit the $\mathrm{DOI}$ to the publisher's website.

- The final author version and the galley proof are versions of the publication after peer review.

- The final published version features the final layout of the paper including the volume, issue and page numbers.

Link to publication

\section{General rights}

Copyright and moral rights for the publications made accessible in the public portal are retained by the authors and/or other copyright owners and it is a condition of accessing publications that users recognise and abide by the legal requirements associated with these rights.

- Users may download and print one copy of any publication from the public portal for the purpose of private study or research.

- You may not further distribute the material or use it for any profit-making activity or commercial gain

- You may freely distribute the URL identifying the publication in the public portal.

If the publication is distributed under the terms of Article 25fa of the Dutch Copyright Act, indicated by the "Taverne" license above, please follow below link for the End User Agreement:

www.tue.nl/taverne

Take down policy

If you believe that this document breaches copyright please contact us at:

openaccess@tue.nl

providing details and we will investigate your claim. 


\title{
Molten Salts in a Bubble Column Reactor as Catalysts for the Oxidative Coupling of Methane
}

\author{
Jan W. M. H. Geerts, Han M. N. van Kasteren, and Kees van der Wiele \\ Eindhoven University of Technology, Laboratory of Chemical Process Technology, PO Box 513, 5600 MB Eindhoven, \\ The Netherlands
}

Liquid lithium carbonate is a catalyst for the oxidative coupling of methane and the catalysis is promoted by addition of solid magnesium oxide particles.

Oxidative coupling of methane is a very promising new route for the production of ethylene from natural gas. ${ }^{1}$ Many materials have been reported to be catalytically active for this process, ${ }^{2-8}$ especially lithium doped magnesium oxide. ${ }^{7-11}$ This catalyst system was first reported by Lunsford and coworkers and is still among the best performing catalysts. ${ }^{9,10}$ In earlier reported work ${ }^{14}$ it appeared possible to use pure $\mathrm{Li}_{2} \mathrm{CO}_{3}$ supported on $\mathrm{ZrO}_{2}$ as a catalyst with similar behaviour to $\mathrm{Li} / \mathrm{MgO}$, albeit that its stability appeared very limited. It was proposed that $\mathrm{Li}_{2} \mathrm{CO}_{3}$ is an active catalyst or catalyst precursor in $\mathrm{Li} / \mathrm{MgO}$. As for the $\mathrm{Li} / \mathrm{MgO}$ catalyst, the $\mathrm{C}_{2}$ selectivity has an optimum with respect to the amount of lithium loading as shown in Figure 1. This optimum shifts to higher loadings when the reaction temperature is increased. It is of interest to know if this trend continues. Therefore, the catalytic activities of lithium carbonate, pure and doped with minor amounts of magnesium oxide, have been tested.

Lithium carbonate melts at $723^{\circ} \mathrm{C}$, which makes it impossible to investigate the catalytic activity of pure lithium carbonate or heavily doped $\mathrm{Li} / \mathrm{MgO}$ catalysts in a fixed-bed

Table 1. The influences of temperature on the catalytic performance of pure lithium carbonate. $P 1$ bar; feed $\mathrm{CH}_{4}: \mathrm{O}_{2}: \mathrm{He}: \mathrm{CO}_{2}$, $1: 0.23: 0.67: 0.022$ (flow rate ratios).

\begin{tabular}{cccrrrrr}
$T /$ & \multicolumn{4}{c}{ Conv./\% } & & \multicolumn{4}{c}{ Selectivity/\% } \\
${ }^{\circ} \mathrm{C}$ & $\mathrm{CH}_{4}$ & $\mathrm{O}_{2}$ & & $\mathrm{C}_{2} \mathrm{H}_{6}$ & $\mathrm{C}_{2} \mathrm{H}_{4}$ & $\mathrm{CO}$ & $\mathrm{CO}_{2}$ \\
700 & 16.9 & 82.6 & & 19.4 & 35.2 & 5.9 & 39.4 \\
750 & 12.6 & 97.9 & & 2.1 & 5.5 & 24.9 & 67.6 \\
800 & 12.2 & 98.5 & 0.0 & 2.4 & 28.4 & 69.3
\end{tabular}

reactor at higher temperatures. The lithium carbonate would just melt and trickle downwards in the reactor. Therefore, a bubble column reactor was developed in our laboratory in order to investigate liquid catalyst systems.

The reactions were carried out in a micro-flow reactor system operated at atmospheric pressure, as described elsewhere, ${ }^{11}$ in which the fixed bed reactor is replaced by a bubble column reactor. The reactor, made of quartz, had an inner diameter of $0.016 \mathrm{~m}$ and a column length of $0.2 \mathrm{~m}$. Methane, oxygen, helium, and carbon dioxide were fed to the reactor through a central dip pipe (outer diam. $0.004 \mathrm{~m}$ ) at feed rates of $19.5,4.4,13.0$, and $0.43 \mathrm{~cm}^{3} \mathrm{~min}^{-1}$ at STP, respectively. The methane/oxygen ratio was 4.4 and the dilution with helium ensured that the reaction heat produced did not influence the reactor temperature. This temperature was kept uniform over the whole bubble column by inserting it in an air fluidised sand bed which was electrically heated. The carbon dioxide partial pressure inside the reactor was kept at 0.01 bar ( 1 bar $=10^{5} \mathrm{~Pa}$ ) by addition of $\mathrm{CO}_{2}$ to the feed. This was sufficiently high to keep the lithium in its carbonate form, in

Table 2. The influences of temperature and $w t \% \mathrm{MgO}$ in the liquid phase on the catalytic performance, $P 1$ bar; feed $\mathrm{CH}_{4}: \mathrm{O}_{2}: \mathrm{He}: \mathrm{CO}_{2}$, $1: 0.23: 0.67: 0.022$ (flow rate ratios).

\begin{tabular}{|c|c|c|c|c|c|c|c|}
\hline \multirow{2}{*}{$\begin{array}{l}\mathrm{MgO} / \\
\mathrm{wt} \%\end{array}$} & \multirow{2}{*}{$\begin{array}{l}T / \\
{ }^{\circ} \mathrm{C}\end{array}$} & \multicolumn{2}{|c|}{ Conv. $1 \%$} & \multicolumn{4}{|c|}{ Selectivity/\% } \\
\hline & & $\mathrm{CH}_{4}$ & $\mathrm{O}_{2}$ & $\mathrm{C}_{2} \mathrm{H}_{6}$ & $\mathrm{C}_{2} \mathrm{H}_{4}$ & $\mathrm{CO}$ & $\mathrm{CO}_{2}$ \\
\hline 2 & 750 & 12.7 & 96.5 & 2.4 & 2.9 & 40.7 & 54.0 \\
\hline & 800 & 14.0 & 96.9 & 3.8 & 17.9 & 19.8 & 58.5 \\
\hline 50 & 750 & 17.2 & 99.6 & 9.9 & 33.2 & 4.3 & 52.6 \\
\hline & 800 & 16.7 & 99.6 & 5.3 & 36.2 & 4.3 & 54.2 \\
\hline
\end{tabular}




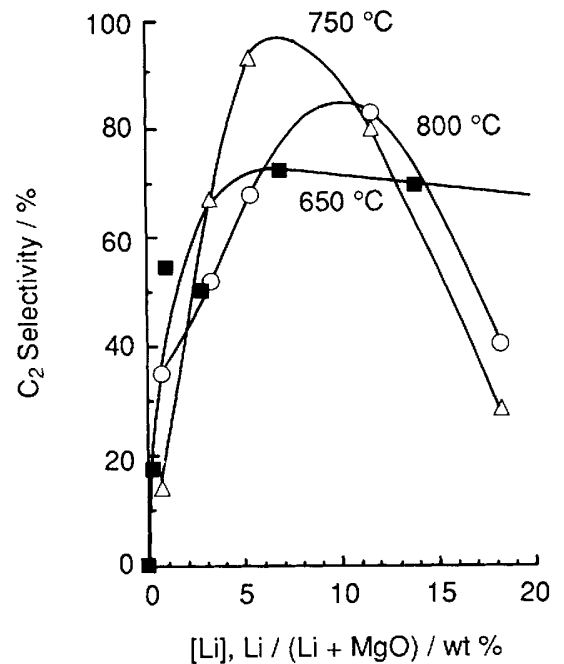

Figure 1. $\mathrm{C}_{2}$ hydrocarbon selectivity vs. lithium concentration and temperature. $P 1$ bar, $\mathrm{CH}_{4} / \mathrm{O}_{2} 10, W / F 0.5 \mathrm{~g} \mathrm{~s} \mathrm{~cm}^{-3}$ at STP; data at $650^{\circ} \mathrm{C}$ see ref. 10 .

agreement with thermodynamic calculations. Lithium carbonate (Merck extra pure) and MgO (Merck p.a.) were used as the starting materials for the catalysts, which were made by slurrying the solids in water followed by evaporation, drying, and grinding. ${ }^{11}$ No calcination took place before reaction. Conversions and selectivities were calculated on carbon bases.

In an empty apparatus the main product is carbon monoxide. Its selectivity is about $60 \%$. The oxygen conversion amounts to $45 \%$ at the same flow rates as applied in the experiments (Tables 1 and 2) and at $700^{\circ} \mathrm{C}$. When the flow rate is increased by a factor of only 1.27 , the oxygen conversion drops to $25 \%$. However, the residence time in the bubble column reactor can roughly be estimated, by using a correlation of Hughmark, ${ }^{12}$ to be $1 / 30$ of that of the empty reactor. Thus, we do not expect any serious gas phase activation where the reactor is filled with catalyst; see also Figure 3 of ref. 13, which shows the dependence of residence time for homogeneous gas phase reactions.

Table 1 shows the catalytic performance of solid and liquid lithium carbonate $(18 \mathrm{~g})$ as a function of temperature. The methane conversion decreases slightly, but the oxygen conversion increases with temperature, which is accompanied by a dramatic loss of hydrocarbon selectivity. Although the experimental conditions have been kept the same, it is clear that the gas contact of solid and liquid lithium carbonate is different. However, it is acceptable to compare their selectivities, for the conversion levels are almost the same. From 700 to $800{ }^{\circ} \mathrm{C}$ the $\mathrm{C}_{2}$ selectivity drops from 55 to only $2.4 \%$. Qualitatively this is in agreement with the reaction mechanism proposed, ${ }^{11}$ which is based on experiments with a $7 \mathrm{wt} \%$ $\mathrm{Li} / \mathrm{MgO}$ catalyst. At higher temperatures, consecutive reactions, i.e., the oxidation of $\mathrm{C}_{2}$ hydrocarbons, become more important and cause the selectivity drop. Despite the decrease in specific surface when $\mathrm{Li}_{2} \mathrm{CO}_{3}$ melts, the activity, in terms of oxygen conversion, increases.

To investigate the influence of magnesium oxide on the catalytic behaviour of lithium carbonate, catalysts with different $\mathrm{MgO} / \mathrm{Li}_{2} \mathrm{CO}_{3}$ ratios were prepared. Under the reaction conditions, magnesium oxide is present as a solid powder, suspended in the liquid. The presence of magnesium oxide has a significant effect on the selectivity, particularly at the high concentration level (compare Tables 2 and 1). This proves that the $\mathrm{Li} / \mathrm{MgO}$ catalyst is not just a carrier covered with a molten $\mathrm{Li}_{2} \mathrm{CO}_{3} / \mathrm{Li}_{2} \mathrm{O}$ phase, but that magnesium oxide plays an essential role. Former investigations ${ }^{13}$ have shown that deactivation of the lithium doped magnesium oxide catalysts occurred in a fixed-bed reactor, but deactivation was not observed here. This can be explained by two facts. Firstly, there is no loss of $\mathrm{Li}$ or possible segregation of $\mathrm{Li}$ and $\mathrm{MgO}$ in the slurry system, in which there is an abundance of liquid $\mathrm{Li}_{2} \mathrm{CO}_{3}$. Therefore the composition is not changing. Secondly, the co-feed of $\mathrm{CO}_{2}$ might also be important, as Korf et al. ${ }^{14}$ have shown that it stabilizes these catalysts.

In conclusion, it can be said that minor amounts of higher hydrocarbons were obtained from molten lithium carbonate. However, addition of magnesium oxide to lithium carbonate is very beneficial for the production of ethane and ethylene and opens the possibility for the creation of (new) active centres. These centres could be mainly responsible for the catalytic coupling activity, as it is known that only a small part of the total $\mathrm{Li}$ content in $\mathrm{Li} / \mathrm{MgO}$ causes the high activity observed during methane coupling. ${ }^{15}$ In this respect, it can be said that the interaction of $\mathrm{Li}$ with $\mathrm{Mg}$ is essential for a high $\mathrm{C}_{2}$ yield. Addition of other components to molten $\mathrm{Li}_{2} \mathrm{CO}_{3}$, as recently reported by Conway et al. ${ }^{16}$ is believed to result in improved catalysts. For reasons of heat removal, a bubble column reactor might be a suitable reactor for a methane oxidative coupling process. However, further research in order to develop improved catalysts has to be done.

We thank the European Communities in the framework of the Non-Nuclear Energy R\&D programme, subprogramme 'Hydrocarbons,' under contract no. EN3C-0038-NL (GDF), and the Netherlands Organization of Scientific Research (NWO) for financial support. We also thank J. Crèvecoeur, E. Geelen, H. P. C. Hopstaken, and H. L. P. Poels for their contributions to this article.

\section{Received, 13th December 1989; Com. 9/05321B}

\section{References}

1 J. W. M. H. Geerts, J. H. B. J. Hoebink, and K. van der Wiele, to be presented at the Boston ACS Meeting, April 22-27, 1990.

2 K. Aika, T. Moriyama, N. Takasaki, and E. Iwamatsu, J. Chem. Soc., Chem. Commun., 1986, 1210.

3 K. Aika and T. Nishiyama, J. Chem. Soc., Chem. Commun., 1988,70

4 J. Carreiro, G. Follmer, L. Lehmann, and M. Baerns, 'Proceedings 9th ICC,' eds. M. J. Phillips and M. Ternan, Calgary, Canada, 1988, pp. 891-898.

5 C. A. Jones, J. J. Leonard, and J. A. Sofranko, US Pat $4,443,644-4,443,649$ and $4,444,984$.

6 K. Otsuka, K. Jinno, and A. Morikawa, Chem. Lett., 1985, 499.

7 K. Otsuka, J. Jpn. Pet. Inst., 1987, 30(6), 385.

8 J. A. Roos, A. G. Bakker, H. Bosch, J. G. van Ommen, and J. R. H. Ross, Catal. Today, 1987, 1, 133.

9 D. J. Driscoll, W. Martir, J.-X. Wang, and J. H. Lunsford, J. Am. Chem. Soc., 1985, 107, 58 .

10 T. Ito, J.-X. Wang, C.-H. Lin, and J. H. Lunsford, J. Am. Chem. Soc., 1985, 107, 5062 .

11 J. W. M. H. Geerts, J. M. N. van Kasteren, and K. van der Wiele, Catal. Today, 1989, 4, 453.

12 G. A. Hughmark, Ind. Eng. Chem. Process Res. Dev., 1967, 6, 218.

13 J. M. N. van Kasteren, J. W. M. H. Geerts, and K. van der Wiele, 'Proceedings 9th ICC,' eds. M. J. Phillips and M. Ternan, Calgary, Canada, 1988, pp. 930-936.

14 S. J. Korf, J. A. Roos, N. A. de Bruin, J. G. van Ommen, and J. R. H. Ross, J. Chem. Soc., Chem. Commun., 1987, 1433.

15 J. M. N. van Kasteren, J. W. M. H. Geerts, and K. van der Wiele, 'Proceedings 1st World Congress, New developments in selective oxidation,' eds. G. Centi and F. Trifiro, Rimini, 1989.

16 S. J. Conway, J. Szanyi, and J. H. Lunsford, Appl. Catal., 1989, 56, 149. 